\title{
In vitro Assessment of Antimicrobial Activity of A1 and A2 Milk Derived Casein Hydrolysate
}

\author{
Lalita Garg $^{1 *}$, Geeta Chauhan ${ }^{1}$, Kamal Kumar ${ }^{2}$ and Neha Thakur ${ }^{3}$ \\ ${ }^{1}$ Division of Livestock Products Technology, ${ }^{2}$ Division of Extension Education, Indian \\ Veterinary Research Institute, Izatnagar, Bareilly, Uttar Pradesh (India) \\ ${ }^{3}$ Division of Livestock Products Technology, Lala Lajpat Rai University of Veterinary and \\ Animal Sciences, Hisar, Haryana (India) \\ *Corresponding author
}

\section{A B S T R A C T}

\begin{tabular}{l} 
Ke y w o r d s \\
$\begin{array}{l}\text { Antimicrobial } \\
\text { activity, A1 and A2 } \\
\text { milk, Growth } \\
\text { promoter, Casein } \\
\text { hydrolysate }\end{array}$ \\
\hline Article Info \\
$\begin{array}{l}\text { Accepted: } \\
\text { 17 November } 2020 \\
\text { Available Online: } \\
\text { 10 December } 2020\end{array}$
\end{tabular}

\section{Introduction}

Casein is deemed as the major source of essential amino acids and has high biological value. Casein consists of four fractions, namely $\alpha$ s $1, \alpha \mathrm{s} 2, \beta$ and $\kappa$-casein. $\beta$-casein has two variants $\mathrm{A} 1$ and $\mathrm{A} 2$ on the basis of the presence of amino acid at $67^{\text {th }}$ position. Enzymatic cleavage of A $1 \beta$-casein lead to the production of seven amino acid peptide, known as $\beta$-casomorphin7 (BCM-7), whereas no $\mathrm{BCM}-7$ is produced upon digestion of $\mathrm{A} 2$
The present study was designed to test the antimicrobial activity of A1 and A2 milk derived casein hydrolysate on Listeria monocytogenes ATCC19115, Staphylococcus aureus ATCC25924, Salmonella typhi MTCC3917 and Pseudomonas aeruginosa MTCC1688. Milk was collected from cattle belonging to A1A1 and A2A2 genotyped from Cattle and Buffalo Farm, ICAR-IVRI, Izatnagar. The cows used for the study belonged to definite genotype as designated by AGB Division, ICAR-IVRI, Izatnagar. Results showed no antimicrobial activity for A1 and A2 casein hydrolysate; instead it was acting as a bacterial growth promoter. No significant difference $(\mathrm{p}>0.05)$ was observed between A1 and A2 casein hydrolysates in bacterial growth of Staphylococcus aureus ATCC25924, Salmonella typhi MTCC3917 and Pseudomonas aeruginosa MTCC1688 at $0 \mathrm{~h}, 2 \mathrm{~h}, 4 \mathrm{~h}$ and $6 \mathrm{~h}$ of hydrolysis except in case of Listeria monocytogenes ATCC19115 at $4 \mathrm{~h}$ only. No antimicrobial activity was observed for casein hydrolysate instead it was acting as a bacterial growth promoter, which can be used as supplement in growth media. 
in functional foods and nutraceuticals. Antimicrobial peptides consist of 12-100 amino acids, comparatively short and have a net positive charge. Antimicrobial peptides did not get much recognition due to their low efficiency and high cost of production against traditional antibiotics (Lahov and Regelson, 1996). Currently, there is a growing interest in the use of these antimicrobial peptides as food preservatives or as healthy dietary supplements. Cationic component of antimicrobial peptides interacts with an anionic component of gram positive and gram negative bacteria, resulting in neutralization of charge on the microbial surface, leading to disruption of the cellular envelope and increase the permeability of cell (Oren, 1999). In some cases, antimicrobial peptides lead to the formation of pores in the cell envelope, leading to leakage of cell contents and ultimately resulting in cell death ( $\mathrm{He}$ et al., 1996). Antimicrobial peptides distort the microbial cell membrane via negatively charged electrostatic interaction, inhibiting the synthesis of protein, DNA and ribonucleic acid (RNA) or interacting with intracellular targets (Bahar and Ren, 2013). Casein-derived bioactive peptides have shown antimicrobial activity against Salmonella, Escherichia and Listeria (Haque and Chand, 2008).

\section{Materials and Methods}

Milk was collected from cattle belonging to $\mathrm{A} 1 \mathrm{~A} 1$ and $\mathrm{A} 2 \mathrm{~A} 2$ genotyped from Cattle and Buffalo Farm, ICAR-IVRI, Izatnagar. The cows used for the study belonged to definite genotype as designated by AGB Division, ICAR-IVRI, Izatnagar.

\section{Preparation of A1 and A2 casein hydrolysates by enzymatic hydrolysis}

The cow milk casein powder was prepared according to the method as narrated by Salami et al., (2011) with slight modification. Cow milk whole casein solutions $(5 \% \mathrm{w} / \mathrm{v}$ on total solid basis) were made by reconstituting the casein in distilled water. The casein solution was heated in boiling water bath for 5 min to destroy the microorganisms, if present, which may produce proteolytic enzymes during hydrolysis process and to denature the native enzymes of the milk, if present, as well as to heat denature the proteins, which increase its susceptibility to proteolytic enzymes. Enzyme/substrate ratio of 1:100 (w/w) was kept constant for trypsin. The temperature and $\mathrm{pH}$ of trypsin were adjusted to $37^{\circ} \mathrm{C}$ and 8.0 respectively. The hydrolysis was achieved by incubating the samples at $37{ }^{\circ} \mathrm{C}$ for trypsin in stirred water bath and samples were drawn after definite time interval i.e. $2 \mathrm{~h}, 4 \mathrm{~h}$ and $6 \mathrm{~h}$ of incubation. Each hydrolyzed sample was instantly warmed to $85{ }^{\circ} \mathrm{C}$ for $15 \mathrm{~min}$. in water bath to inactivate the enzymes left in the hydrolysates. Then the samples were cooled and centrifuged in the refrigerated centrifuge at $10,000 \mathrm{rpm}$ for $20 \mathrm{~min}$, supernatants were collected and stored at -20 ${ }^{\circ} \mathrm{C}$ until further use and samples were coded as A1 and A2 casein hydrolysate.

\section{Bacterial growth inhibition assay}

The four tested bacterial strains (Listeria monocytogenes ATCC19115, Staphylococcus aureus ATCC25924, Salmonella typhi MTCC3917 and Pseudomonas aeruginosa MTCC1688) were cultured in brain heart infusion (BHI) broth as described by Kouadio et al., (2011). Undigested and digested samples were sterilized by filtration into a $0.22-\mu \mathrm{m}$-pore-size membrane filter. The antimicrobial test was performed in a sterile 96-well microplate, which was incubated at $37^{\circ} \mathrm{C}$ for $24 \mathrm{~h}$. Optical density at $600 \mathrm{~nm}$ (OD $600 \mathrm{~nm}$ ) was recorded after $24 \mathrm{~h}$ using a Microplate reader (Thermo Fisher Scientific). Volumes of $100 \mu \mathrm{l}$ of overnight cultures Listeria monocytogenes ATCC19115, Staphylococcus aureus ATCC25924, 
Salmonella typhi MTCC3917 and Pseudomonas aeruginosa MTCC1688 previously diluted in BHI broth, used to inoculate each well containing $100 \mu \mathrm{l}$ of digested or undigested casein sample. In addition to the positive controls, negative controls were also included. The percentage of inhibition of bacterial growth after $24 \mathrm{~h}$ of incubation at $37{ }^{\circ} \mathrm{C}$ was estimated by comparing $\mathrm{OD}_{600 \mathrm{~nm}}$ values measured with the mean values of the positive controls.

\section{Results and Discussion}

Although most of the studies had shown antimicrobial effect of casein hydrolysates, but in present study no antimicrobial activity was observed from A1 and A2 casein hydrolysates against all targeted bacteria by well diffusion, disc diffusion and microdilution method.

In the present study $\mathrm{A} 1$ and $\mathrm{A} 2$ casein hydrolysates at $5 \%$ concentration, was initially tested for antimicrobial activity against each two Gram positive (Listeria monocytogenes ATCC19115 and Staphylococcus aureus ATCC25924) and Gram negative (Salmonella typhi MTCC3917 and Pseudomonas aeruginosa MTCC1688) foodborne bacteria by using agar well diffusion and disc diffusion assay on BHI plates. No zone of inhibition was observed against any targeted bacteria by A1 and A2 casein hydrolysates at $0 \mathrm{~h}, 2 \mathrm{~h}, 4 \mathrm{~h}$ and $6 \mathrm{~h}$ of hydrolysis, which might be due to nondiffusibility of peptides.

Then, antimicrobial activity was studied by using much sensitive micro-dilution method. Results in Table 1 showed a clear increase in the OD values of A1 and A2 casein hydrolysates when added to growth media for study purpose. The $\mathrm{OD}_{600 \mathrm{~nm}}$ of both $\mathrm{A} 1$ and A2 casein hydrolysates were higher than the control sample. Consequently, it was suggested that no antimicrobial activity was observed in both A1 and A2 casein hydrolysates at $5 \%$ casein concentration at 0 $\mathrm{h}, 2 \mathrm{~h}, 4 \mathrm{~h}$ and $6 \mathrm{~h}$ of hydrolysis. No significant difference $(p>0.05)$ was observed between A1 and A2 casein hydrolysates in bacterial growth of Listeria Staphylococcus aureus ATCC25924, Salmonella typhi MTCC3917 and Pseudomonas aeruginosa MTCC1688 at $0 \mathrm{~h}, 2 \mathrm{~h}, 4 \mathrm{~h}$ and $6 \mathrm{~h}$ of hydrolysis. In case of Listeria monocytogenes ATCC19115, significant difference $(\mathrm{p}<0.05)$ was observed between $\mathrm{A} 1$ and $\mathrm{A} 2$ casein hydrolysates at $4 \mathrm{~h}$ only, showing higher for A2.

The differentiation of bacterial growth within the groups showed that significant difference $(\mathrm{p}<0.05)$ was observed only in case of Pseudomonas aeruginosa MTCC1688, where A1 casein hydrolysate showed significant $(\mathrm{p}<0.05)$ decrease at $2 \mathrm{~h}$ followed by further non-significant variation $(p>0.05)$.

The results of present study was supported with the finding of St-Gelais et al., (1993), who reported that casein hydrolyzed with trypsin and alcalase was rich in amino acids and peptides that could be used to supplement culture medium and to promote the growth of Lactococci, moreover some strains of Lactococci grew better in culture media enriched with casein hydrolysates that has high molecular weight peptide, where as other strains preferred culture media with lower molecular weight peptides.

The results are in concurrence with Gray et al., (2008), who reported that pancreatin and $\mathrm{HCl}$ digests of casein had shorter generation interval for Escherichia coli, Salmonella ser. Poona, Salmonella ser. Typhimurium and Staphylococcus aureus and acting as better peptones than gelatine, meat, soy and yeast extract. 
Table.1 Effect of A1 and A2 casein hydrolysates by trypsin (5\%) on bacterial growth by micro-dilution method at various time periods of hydrolysis (growth rate in terms of OD $600 \mathrm{~nm}$ ) $($ Mean \pm SE)

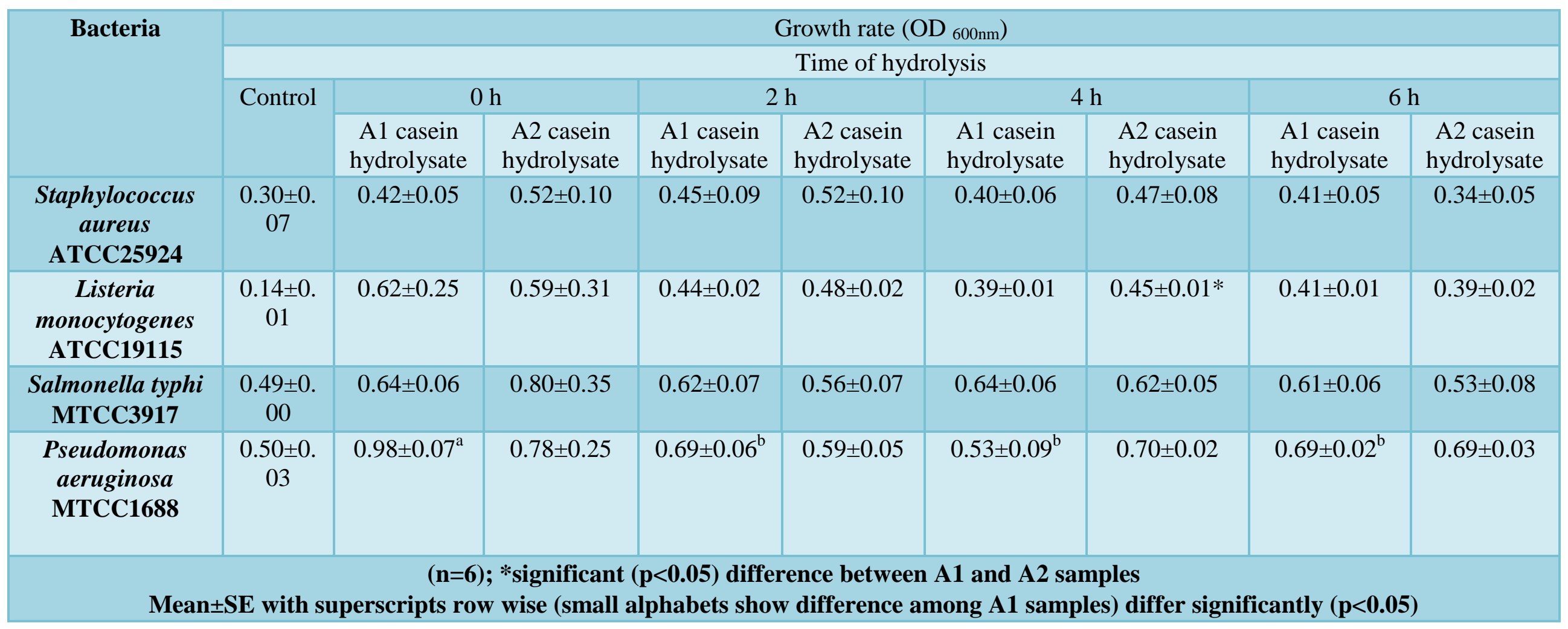


Similar to the present finding, Poch and Bezkorovainy (1988) elucidated that bovine casein digests was promoting the growth of Bifidobacterium sp. as it serve a source of nitrogen and unknown growth factor for bacteria. Higuchi and Carlin (1957) reported that casein hydrolysate was better growth medium for Pasteurella pestis.

In conclusion the no antimicrobial activity was observed for casein hydrolysate instead acting as bacterial growth promoter, which can be used as supplement in growth media. Further, No significant difference $(p>0.05)$ was observed between $\mathrm{A} 1$ and $\mathrm{A} 2$ casein hydrolysates in bacterial growth of Staphylococcus aureus ATCC25924, Salmonella typhi MTCC3917 and Pseudomonas aeruginosa MTCC1688 at $0 \mathrm{~h}$, $2 \mathrm{~h}, 4 \mathrm{~h}$ and $6 \mathrm{~h}$ of hydrolysis except in case of Listeria monocytogenes ATCC19115 at $4 \mathrm{~h}$ only.

However, The present results are not in agreement with Recio and Visser (1999), Bougherra et al., (2017), Lopez-Exposito et al., (2007), which might be due to the utilization of different enzyme i.e. trypsin, production of different pattern of peptides upon hydrolysis or the less amount of antimicrobial peptides as compared to the bacterial growth promoting peptides, which could only be confirmed by further isolation of specific peptide sequence having antimicrobial activity and not opted in the present study.

\section{References}

Bahar, A. and Ren, D. 2013. Antimicrobial peptides. Pharm. 6(12): 1543-1575.

Bougherra, F., Dilmi-Bouras, A., Balti, R., Przybylski, R., Adoui, F., Elhameur, H., Chevalier, M., Flahaut, C., Dhulster, P. and Naima, N. 2017. Antibacterial activity of new peptide from bovine casein hydrolyzed by a serine metalloprotease of Lactococcus lactis subsp lactis BR16. J. Funct. Foods. 32: 112-122.

FitzGerald, R.J., Murray, B.A. and Walsh, D.J. 2004. Hypotensive peptides from milk proteins. J. Nutr. 134(4): 980-988.

Gray, V.L., Müller, C.T., Watkins, I.D. and Lloyd, D. 2008. Peptones from diverse sources: pivotal determinants of bacterial growth dynamics. J. Appl. Microbiol. 104(2): 554-565.

Haque, E. and Chand, R. 2008. Antihypertensive and antimicrobial bioactive peptides from milk proteins. Eur. Food Res. Technol. 227(1): 7-15.

He, K., Ludtke, S.J., Heller, W.T. and Huang, H.W. 1996. Mechanism of alamethicin insertion into lipid bilayers. Biophys. J. 71(5): 2669-2679.

Higuchi, K. and Carlin, C.E. 1957. Studies on the nutrition and physiology of Pasteurella pestis: I. A Casein Hydrolyzate Medium for the Growth of Pasteurella pestis. J. Bacteriol. 73(1): 122.

Kitts, D.D. and Weiler, K. 2003. Bioactive proteins and peptides from food sources. Applications of bioprocesses used in isolation and recovery. Curr. Pharm. Des. 9(16): 1309-1323.

Kouadio, A.I., Oulahal, N., Thi, P.N., Adt, I. and Degraeve, P. 2011. Study of the antimicrobial activities of Solanum indicum ssp. distichum (Schumach. and Thonning 1827) fruits ("gnangnan" berries) from a tropical humid zone (Côte d'Ivoire). Int. J. Bio. Chem. Sci. 5(3).

Lahov, E. and Regelson, W. 1996. Antibacterial and immunostimulating casein-derived substances from milk: casecidin, isracidin peptides. Food Chem. Toxicol. 34(1): 131-145.

Lopez-Exposito, I., Quiros, A., Amigo, L. and 
Recio, I. 2007. Casein hydrolysates as a source of antimicrobial, antioxidant and antihypertensive peptides. Le Lait. 87(45): 241-249.

Oren, A. 1999. Bioenergetic aspects of halophilism. Microbiol. Mol. Biol. Rev. 63(2): 334-348.

Poch, M. and Bezkorovainy, A. 1988. Growth-enhancing supplements for various species of the genus Bifidobacterium. J. Dairy Sci. 71(12): 3214-3221.

Recio, I. and Visser, S. 1999. Identification of two distinct antibacterial domains within the sequence of bovine as2- casein. Biochim. Biophys. Acta. 1428(23): 314-326.

Salami, M., Moosavi-Movahedi, A. A., Moosavi-Movahedi, F., Ehsani, M. R., Yousefi, R., Farhadi, M. and Haertle, T. 2011. Biological activity of camel milk casein following enzymatic digestion. J. Dairy Res. 78(4): 471-478.

St-Gelais, D., Roy, D., Hache, S., Desjardins, M.L. and Gauthier, S.F. 1993. Growth of nonproteolytic Lactococcus lactis in culture medium supplemented with different casein hydrolyzates. J. Dairy Sci. 76(11): 3327-3337.

\section{How to cite this article:}

Lalita Garg, Geeta Chauhan, Kamal Kumar and Neha Thakur. 2020. In vitro Assessment of Antimicrobial Activity of A1 and A2 Milk Derived Casein Hydrolysate. Int.J.Curr.Microbiol.App.Sci. 9(12): 2351-2356. doi: https://doi.org/10.20546/ijcmas.2020.912.279 